\title{
Neuronal-glial networks as substrate for CNS integration
}

\author{
A. Verkhratsky a, *, E. C. Toescu ${ }^{b}$ \\ ${ }^{a}$ Faculty of Life Sciences, The University of Manchester, Manchester, UK \\ ${ }^{b}$ Department of Physiology, Division Medical Sciences, The University of Birmingham, Birmingham, UK
}

Received: August 2, 2006; Accepted: October 3, 2006

\section{- Introduction}

- Neuronal and glial networks: glial cells form continuous syncytium

- Neurones and glia: Physiology of signal propagation

- Astrocytes are capable of chemical neurotransmission
- Neurotransmitters released by astrocytes modulate neuronal activity and synaptic transmission

- Astrocytes form functional neuronal-glialvascular units and control microcirculation

- Integration within neuronal-glial networks: Which keys the future holds?

\begin{abstract}
Astrocytes have been considered, for a long time, as the support and house-keeping cells of the nervous system. Indeed, the astrocytes play very important metabolic roles in the brain, but the catalogue of nervous system functions or activities that involve directly glial participation has extended dramatically in the last decade. In addition to the further refining of the signalling capacity of the neuroglial networks and the detailed reassessment of the interactions between glia and vascular bed in the brain, one of the important salient features of the increased glioscience activity in the last few years was the morphological and functional demonstration that protoplasmic astrocytes occupy well defined spatial territories, with only limited areas of morphological overlapping, but still able to communicate with adjacent neighbours through intercellular junctions. All these features form the basis for a possible reassessment of the nature of integration of activity in the central nervous system that could raise glia to a role of central integrator.
\end{abstract}

Keywords: glia $\bullet$ astrocytes $\bullet$ neuronal-glial interactions $\bullet$ plasticity $\bullet$ glutamate

\section{Introduction}

The concept of neuroglia as an interstitial matter which provides a structural basis of the brain and spinal cord and binds neurones together was initially developed by Rudolf Virchow [1], who in fact never considered the cellular nature of this matter; for

\footnotetext{
* Correspondence to: Prof. A. VERKHRATSKY,

Faculty of Life Sciences, The University of Manchester, 1.124

Stopford Building, Oxford Road, Manchester M13 9PT, UK
}

Virchow neuroglia was not more than a sort of extracellular binding element, and he often referred to it as a "Nervwenkitt" (i.e. nerve cement). Very soon, however, the cellular nature of glial cells was identified and many types of neuroglial cells were described

Tel.: (+44 161) 2755414

Fax: (+44 161) 2755948

E-mail: alex.verkhratsky@manchester.ac.uk 
(e.g. $[2,3])$, at a time that still preceded the development of the neuronal doctrine, introduced by von Waldeyer and Exner [4, 5]. Interestingly, already at the end of $19^{\text {th }}$ century, Carl-Ludwig Schleich was the first to propose a theory of neuronal-glial interactions, in which he championed the role of glial cells as equal partners for neurones [6]. Ironically, this theory was never seriously considered by contemporary scientists and for many years the glia was regarded as a mere structural/supportive element in the nervous system [7]. The tide turned in mid 1980s and recently the involvement of glia in formation of CNS circuits become increasingly clear. The present review will reflect the modern view on CNS organisation, based on closely interacting neuronal-glial networks.

\section{Neuronal and glial networks: glial cells form continuous syncytium}

Neuronal networks are physically discontinuous, with neurones being separate entities. This fact, wholly accepted now, emerged gradually, at the turn of the $20^{\text {th }}$ century, from the long-lasting confrontation between the adepts of "reticular theory", who regarded the nervous system as a single intricate reticulum or syncitium (e.g. Gerlah, Kölliker and, most importantly, Golgi) and founders of the "neuronal doctrine", which regarded the nervous system as constructed from separate cellular entities, the neurones (Waldeyer, Exner and most importantly Ramon y Cajal; see [8] for detailed account). The integration and communication within these neuronal networks is provided by specialised structures, the synapses, which are the substrates of chemical neurotransmission [9].

Glial cells in the CNS are represented by three main types: astroglia, oligodendroglia, and microglia. The functions of oligodendrocytes and microglial cells are rather well defined: the former are responsible for myelination and metabolic support of axons, whereas the latter are involved in brain immune reactivity and defence. The astrocytes, in contrast, are much more intimately involved in the formation of CNS cellular circuits and in information processing in the brain. Astroglial networks are fundamentally different from neuronal ones - astrocytes form an internally continuous syncytium. This syncytium is support- ed by direct intercellular contacts, generally known as gap junctions (Fig. 1). The gap junctions are specialised areas, constructed by two apposing membranes of adjacent cells, with an intercellular cleft of just about 2-3 nm. Within these structures, specialised proteins, known as connexins, form intercellular channels, acting as large aqueous pores that connect the cytoplasm of the adjacent cells involved in the junction $[10,11]$. At a molecular level, every intercellular channel is composed of two precisely aligned connexons, or hemichannels composed of six symmetrical subunits, named connexins (hence a functional intercellular channels comprise 2 connexons and 12 connexins). There are many types of connexins, and about 20 subtypes were identified in mammalian tissues. These subtypes differ in molecular weight (varying between $26 \mathrm{kD}$ and $62 \mathrm{kD}$ ); the molecular weight is also used in the connexins nomenclature - e.g. $\mathrm{Cx} 26$ or $\mathrm{Cx} 42$, or Cx57 (see [12-14] for review). Due to their large size (pores with diameter $>1.5$ $\mathrm{nm}$ ), these intercellular channels are permeable to large molecules (molecular weight up to $1 \mathrm{kD}$ ), allowing for intercellular diffusion of many cytoplasmic second messengers (e.g. $\mathrm{InsP}_{3}$ ), nucleotides (ATP, ADP) or even vitamins. Interestingly, the hemichannels do not always form gap junctions, and may exist as stand-alone transmembrane channels, capable of providing a pathway for inward or outward passage of rather large molecules, including some neurotransmitters [15]. Astroglial cells in the CNS have the highest density of gap junctions and connexons and hence the highest degree of intercellular coupling. Indeed, injection of relatively small fluorescent molecules (e.g. Lucifer yellow or Alexa Fluor dyes) into single astrocyte in brain tissue results in staining of about 50-100 neighbouring astroglial cells [16]. Yet the networks formed by gap junctions are not absolutely ubiquitous and the degree of coupling varies considerably between different brain regions. For example almost all cortical astrocytes are integrated into the syncytium, in the optic nerve the degree of coupling reaches $\sim 80 \%$ whereas in the hippocampus it is much lower, being around $\sim 50 \%$. Importantly, gap junction conductance can be regulated by neuronal activity and by various neurotransmitters and hormones, hence linking the degree of coupling in astroglial syncytium to physiologically occurring stimulation [17-19]. 
Fig. 1 Astrocytes integrate brain cells into a functional syncytium. The scheme shows the astrocytes, which form gap junction contacts with oligodendrocytes and ependymal cells, plaster brain vessels with endfeet and receive chemical signals from synapses and neurones.

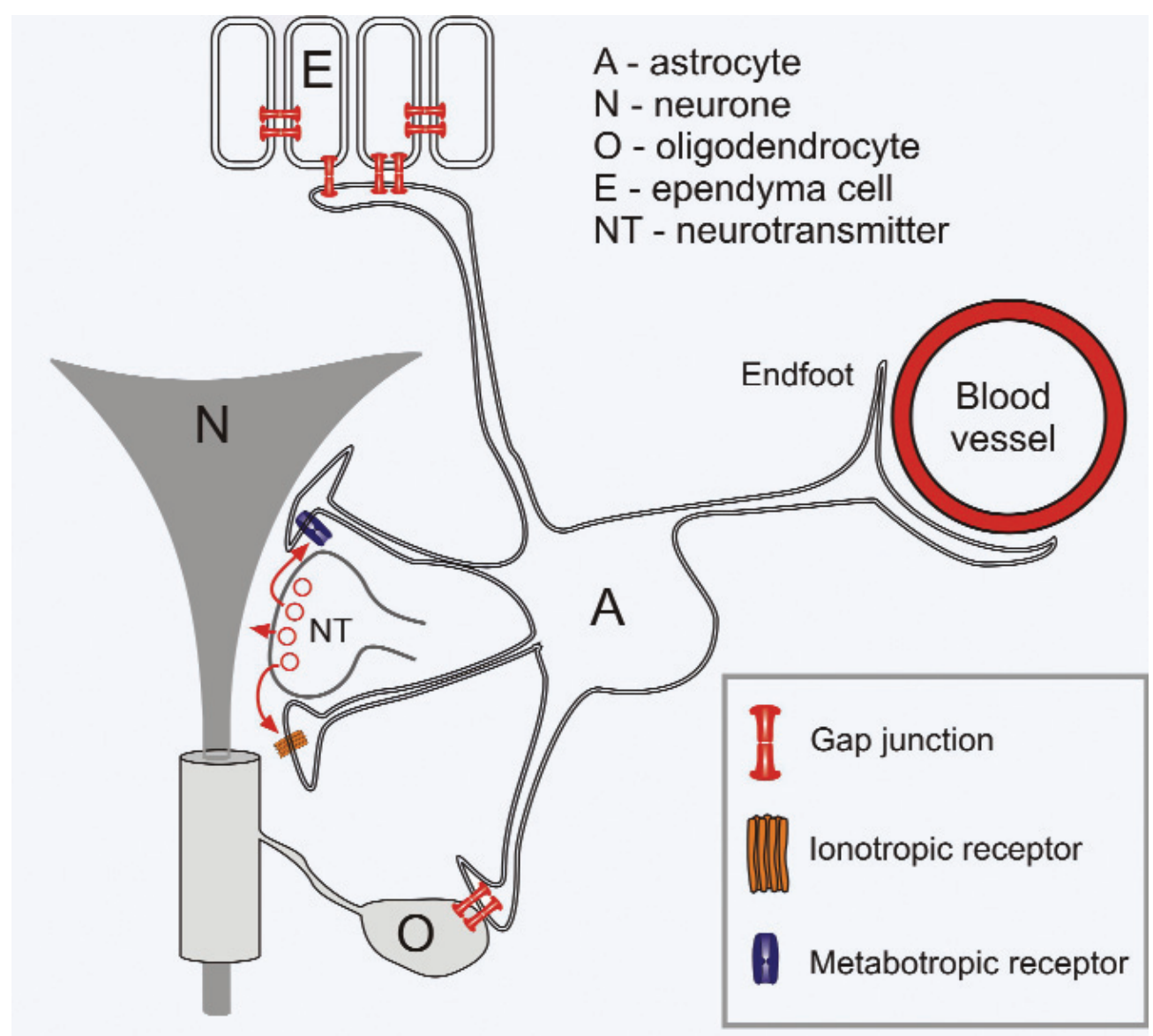

Astrocytes also form gap junctions with oligodendrocytes thus providing a general integrating media, which forms a panglial contacts within the brain [20]. This integration further extends to ependymal cells, as the latter from gap junctions with astrocytes (Fig. 1). Finally, recent data show that astrocytes may occasionally form gap junction contacts with neurones, especially in the early developmental stages [21-24].

\section{Neurones and glia: physiology of signal propagation}

Mechanisms of excitability and signal propagation of neurones and glial cells are fundamentally different. Essentially, neuronal excitability is a form of electrical excitability and is determined by the existence of a specific complement of voltage-gated ion channels $\left(\mathrm{Na}^{+}\right.$channels, $\mathrm{K}^{+}$channels, and, to a lesser extent, $\mathrm{Ca}^{2+}$ channels) in the plasmalemma. Depolarization of the neuronal plasma membrane to a certain threshold activates these channels and generate an action potential that propagates mainly along the axon. Glial cells are electrically nonexcitable and unable to generate plasmalemmal action potentials. However, many types of glial cells do express several types of voltage-gated channels, including $\mathrm{Na}^{+}$and $\mathrm{Ca}^{2+}$ channels (see e.g. [25-30]), but the density of these channels is rather low ( $c a .1000$ times less as compared to neurones), and thus the currents generated upon their activation are unable to substantially depolarise glial membrane [31]. Nevertheless, the glial cells are excitable, in the sense of responding to information from their surrounding; and one of the principal mechanisms used is $\mathrm{Ca}^{2+}$ signalling. The major source of $\mathrm{Ca}^{2+}$ in the glial cells is the endoplasmic reticulum (ER), a large reticular organelle moulded into the intricate network of microtubulae and cisternae; this network forms the nuclear envelope, occupies the cell body and penetrates into cell processes. The ER is a multifunctional organelle, which integrates numerous extra- and intracellular signals, provides for protein synthesis and post- 
translational protein modification, serves as a highway for intracellular transportation of various substances (e.g. transport RNA or secretory products), and generates output signals controlling long-lasting adaptive cellular responses [32-36].

Furthermore, the ER also acts as a dynamic $\mathrm{Ca}^{2+}$ store, able to accumulate, store and release $\mathrm{Ca}^{2+}$ ions $[37,38]$. The concentration of free $\mathrm{Ca}^{2+}$ within the ER lumen $\left(\left[\mathrm{Ca}^{2+}\right]_{\mathrm{L}}\right.$ ) lies in a range of $100-800 \mu \mathrm{M}$ [39-45] and therefore a steep concentration gradient between the ER lumen and the cytosol (where $\mathrm{Ca}^{2+}$ concentration, $\left[\mathrm{Ca}^{2+}\right]_{\mathrm{i}}$, stays within $50-100 \mathrm{nM}$ range) is formed. This concentration gradient drives a rapid $\mathrm{Ca}^{2+}$ release from the ER, which occurs through several types of intracellular $\mathrm{Ca}^{2+}$ channels: (a) the $\mathrm{Ca}^{2+}$-gated channels (generally known as ryanodine receptors, RyRs [46]) or (b) $\mathrm{InsP}_{3}$-gated $\mathrm{Ca}^{2+}$ channels (or InsP receptors, $\mathrm{InsP}_{3} \mathrm{Rs}$ ) residing in the endomembrane [47] or (c) the NAADP receptors, although their exact nature remains unknown [48].

The RyRs are activated by an increase in cytosolic $\mathrm{Ca}^{2+}$ concentration, resulting in $\mathrm{Ca}^{2+}$-induced $\mathrm{Ca}^{2+}$ release, whereas InsP $\mathrm{P}_{3} \mathrm{Rs}$ are under dual control of second messenger $\mathrm{InsP}_{3}$ and intracellular free $\mathrm{Ca}^{2+}$. The positive modulation of both channel types by cytosolic $\mathrm{Ca}^{2+}$ provides for regenerative activation of the endomembrane, when local opening of $\mathrm{Ca}^{2+}$ channels creates local $\mathrm{Ca}^{2+}$ gradients, which in turn activate neighbouring channels, creating thus a propagating wave of channels opening and a propagating wave of $\mathrm{Ca}^{2+}$ release from the ER [49].

Initiation of the $\mathrm{Ca}^{2+}$ signal is normally achieved by activation of various G-protein coupled receptors (GPCRs) that are coupled to phosphopipase C activation, and hence to the synthesis of InsP3; and, glial cells possess a large variety of such receptors (see e.g. [50-53]), that ultimately trigger an $\mathrm{InsP}_{3}$ induced $\mathrm{Ca}^{2+}$ release from the ER. Different types of glial cells also express RyRs [115]), although their functional role remains unclear, as they do not significantly contribute to the generation of $\mathrm{Ca}^{2+}$ signals [54]. The depletion of the ER, which follows the InsP3-induced $\mathrm{Ca}^{2+}$ release, activates store-operated $\mathrm{Ca}^{2+}$ channels, abundantly expressed in all types of glia (see e.g. [55-59]).

Quite often, especially in the in situ situation, the initial $\mathrm{Ca}^{2+}$ release occurs in distant glial processes, i.e. in the actual place of neuronal-glial contacts, and this release is followed by a propagating wave of ER excitation which relays the $\mathrm{Ca}^{2+}$ signal into the soma $[60,61]$. In addition to the evoked $\mathrm{Ca}^{2+}$ signals and intracellular waves, astroglial cells are capable of generating spontaneous $\left[\mathrm{Ca}^{2+}\right]_{\mathrm{i}}$ oscillations, which were detected in astrocytes both in culture and in situ, in hippocampus, thalamus, cerebellum and neocortex [62-65]. Generation of these spontaneous waves involves interactions between $\mathrm{InsP}_{3}$-dependent $\mathrm{Ca}^{2+}$ release and $\mathrm{Ca}^{2+}$ entry, most likely through store-operated $\mathrm{Ca}^{2+}$ channels [64].

In the context of the earlier discussion on the profuse level of intercell communications, it is clear that a wave of ER excitation in astroglial cells does not need stop at the cell borders and it could spreads through the neighbouring glial cells, conveying $\mathrm{Ca}^{2+}$ signals over a long distance (up to $300-400$ $\mu \mathrm{m}$ from the initial foci of excitation - see [66, 67]. The mechanisms of spreading calcium waves in glial cells are complex. They may result from (i) diffusion of $\mathrm{InsP}_{3}$ though gap junctions, (ii) regenerative or single point release of diffusible extracellular messenger (the latter is most likely represented by ATP, which can be secreted from astrocytes via either diffusion through hemichannels or through $\mathrm{Ca}^{2+}$-regulated exocytosis), or (iii) by combination of the above (see e.g. [68-73]). Whatever the actual mechanism, the propagating $\mathrm{Ca}^{2+}$ waves allow astroglial networks to communicate and integrate information at long range.

\section{Astrocytes are capable of chemical neurotransmission}

A further significant extension of the complexity of signal transduction in the brain comes from the capacity of glia to initiate the release of neurotransmitters. The ability to secret neurotransmitters in a regulated fashion was for many years the sole prerogative of neurones; but recent investigations are challenging this dogma. In fact, some initial reports indicating that astroglia are capable to release neuroactive substances, including neurotransmitters such as glutamate, appeared in late 1980s [74]; more recent experiments demonstrate even clearer this process and reveal that astrocytes are capable of regulated exocytotic secretion of numerous mediators Exocytotic release requires both the existence of the secretory vesicles, containing the neurotransmitter, 
and of specific exocytotic proteins. Cytoplasmic vesicles, containing glutamate, were recently found in mature hippocampal astrocytes [75]; some of these vesicles were arranged in groups close to plasmalemma in astroglial perisynaptic expansions. The astroglial vesicles possess vesicle glutamate transporters (VGLUT1-3), and thus are able to accumulate glutamate [75-77]; they also express vesicleassociated protein 3 (VAMP3 or cellubrevin), which regulates exocytotic fusion from the vesicular side [75]. Astrocytes also express plasmalemmal regulators of exocytotic fusion, the SNAP23 (soluble Nethylmaleimide-sensitive fusion protein attachment protein), complexin 2, Munch 18a and synaptotagmin IV. Most importantly the $\left[\mathrm{Ca}^{2+}\right]_{\mathrm{i}}$-induced exocytosis of astroglial vesicles and subsequent release of glutamate were directly visualised by total internal reflection fluorescence imaging [75], and exocytotic fusion following $\left[\mathrm{Ca}^{2+}\right]_{\mathrm{i}}$ signals was also measured by membrane capacitance recordings [78]. The vesicular glutamate release from astrocytes is fundamentally different from the neuronal one in respect to the source of trigger $\mathrm{Ca}^{2+}$ : in astrocytes $\mathrm{Ca}^{2+}$ comes almost exclusively from the intracellular stores, whereas neuronal exocytosis is governed predominantly by $\mathrm{Ca}^{2+}$ entry through plasmalemmal channels $[75,79]$ (for astroglial exocytosis see also a very comprehensive review by Volterra and Meldolesi [80]). As a consequence, vesicular release of neurotransmitter from astroglial cells develops considerably slower as compared to neurones [75].

The range of biologically active substances that can be released by the glia is ever expanding, generating a whole library of gliotransmitters [80]. Most of these substances are released, as discussed above, through a mechanism of $\mathrm{Ca}^{2+}$-dependent exocytosis. Results published in the last couple of years open an entirely new field of transmitter release, which is, at least for the time being, restricted to the glial cells. Astroglial cells have been shown to release transmitters by alternative routes that involve the opening of plasmalemmal channels permeable for relatively large molecules. In particular, glutamate and other amino-acids can be released through hemichannels, through volume-sensitive channels [81] and through P2X7 purinoreceptors [82]. This mechanism of transmitters release through plasmalemmal channels does not depend on $\left[\mathrm{Ca}^{2+}\right]_{\mathrm{i}}$.

\section{Neurotransmitters released by astrocytes modulate both neuronal activity and synaptic transmission}

The astrocyte-to-neurone signalling was demonstrated in several ways, in both in vitro (cell cultures) and in situ (acute brain slices) studies. In glialneuronal co-cultures, release of glutamate from astrocytes may have multiple effects on neuronal synaptic transmission. Stimulation of astrocytes, generating $\left[\mathrm{Ca}^{2+}\right]_{\mathrm{i}}$ signals, resulted in $(i)$ direct excitation of neighbouring neurones via activation of AMPA/NMDA receptors [83, 84] (ii) increase in the frequency of spontaneous (miniature) excitatory and inhibitory postsynaptic currents (via activation of extrasynaptic NMDA receptors and increase in probability of transmitter release) [85] and (iii) inhibition of evoked EPSCs/IPSCs though metabotropic glutamate receptors pathway ([86], see also [87, 88]). All these effects were blocked after inhibition of astroglial $\left[\mathrm{Ca}^{2+}\right]_{\mathrm{i}}$ signalling by either intracellular injection of $\mathrm{Ca}^{2+}$-chelator BAPTA or by inhibition of $\mathrm{ER}^{\mathrm{Ca}^{2+}}$ release by thapsigargin.

In hippocampal and cortical slices, spontaneous astrocytic $\left[\mathrm{Ca}^{2+}\right]_{\mathrm{i}}$ oscillations were found to drive neuronal $\left[\mathrm{Ca}^{2+}\right]_{i}$ signals [89]. Likewise, in thalamus, spontaneous astrocytic $\left[\mathrm{Ca}^{2+}\right]_{i}$ oscillations directly excited adjacent neurones through activation of NMDA receptors residing in the latter [65]. The neuronal $\left[\mathrm{Ca}^{2+}\right]_{\mathrm{i}}$ signals were observed in CA1 hippocampal neurones following astroglial activation by prostaglandin E2. These neuronal $\mathrm{Ca}^{2+}$ signals were detected in conditions of complete inhibition of synaptic neurotransmitter release from neuronal terminals (by slice incubation with tetanus neurotoxin, TeNT) and were mediated by glutamate secreted from astroglial cells [90]. Importantly, glutamate, released from a single astrocyte may act on several adjacent neurones thus producing synchronous excitation of the latter [91].

Astroglial glutamate release may also affect inhibitory pathways in hippocampus, by facilitating GABA release from interneurones connected to pyramidal CA1 cells; an effect mediated by the activation of ionotropic (most likely kainate) glutamate receptors localised on the terminals of these interneurones $[92,93]$.

Astrocytes are able to release not only glutamate but also ATP [94] and D-serine [95], which both may act as neurotransmitters/neuromodulators. 

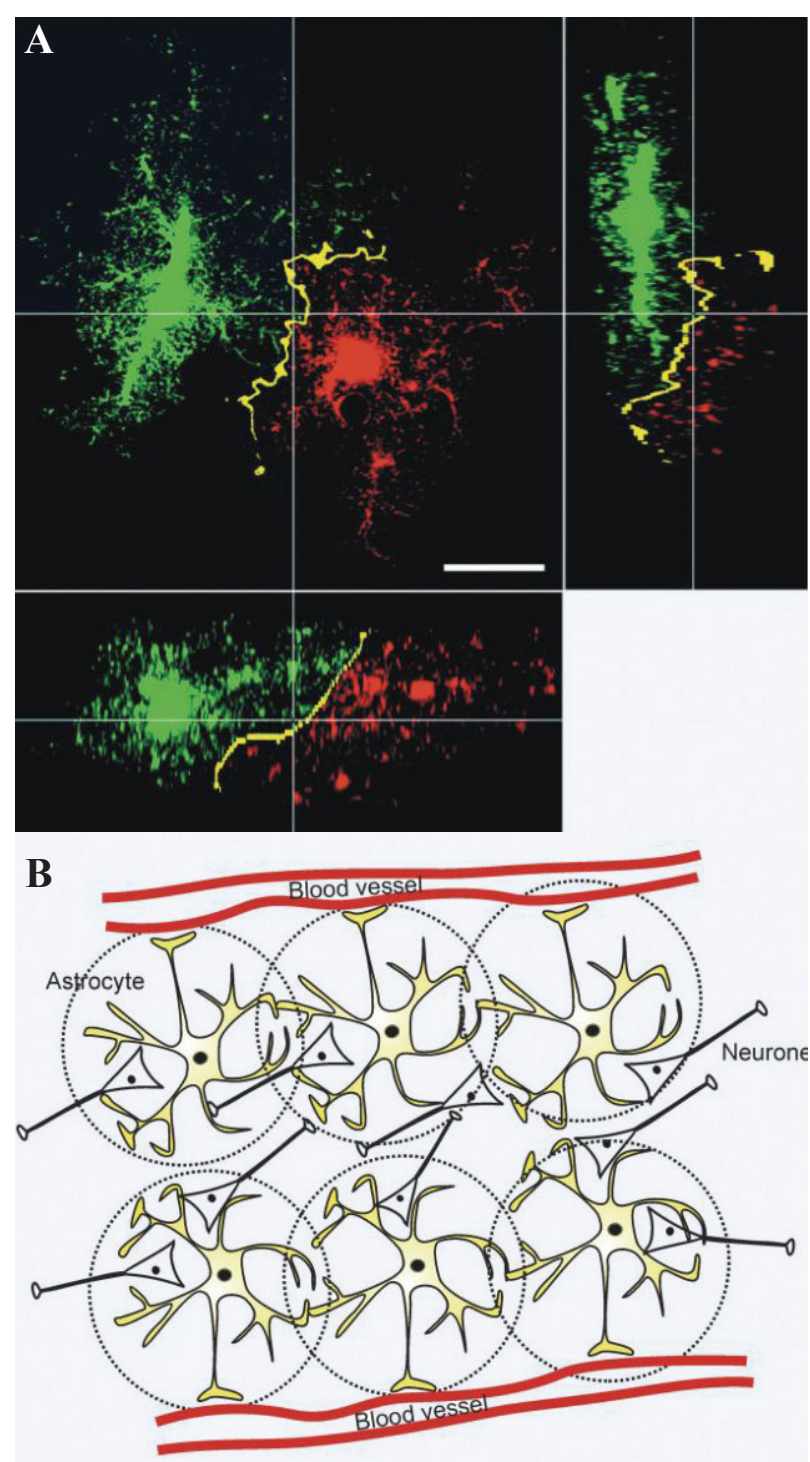

Fig. 2 A. Hippocampal (CA1 area) astrocytes define their exclusive territories in the grey matter. Two adjacent astrocytes were filled with Alexa Fluor 488 (green) and Alexa Fluor 568 (red) through separate patch pipettes. The discreet region of interaction (yellow) between the fine processes of protoplasmic astrocytes. Pixels containing both green and red were determined using the colocalization routine and then pseudocolored in bright yellow to mark their presence. $x-y$ (large panel), $x-z$ (bottom panel), and $y$ $z$ (right panel) slices through the area in which two adjacent astrocytes interface. Scale bar, $20 \mu \mathrm{m}$. From [103], with permission (copyright 2002, Society for Neuroscience). B. Schematic representation of the concept of the Neuronal Glial - Vascular unit. Astroglial cells define their territory with very little overlap between adjacent cells; the astroglial-astroglial contacts are established only between terminal processes. Within the territory each astrocyte contacts the blood vessel and all neuronal membranes, thus forming a functional neuronal-glial-vascular unit.
When released by astroglial cells, these transmitters can affect neuronal electrical activity and synaptic transmission (see e.g. [87, 88, 96, 97] for review). In hippocampal neuronal-glial co-cultures, ATP secreted by astrocytes inhibited glutamatergic synapses via presynaptic P2Y receptors [98]. Alternatively, as was shown in experiments in hippocampal slices, astroglial release of ATP may cause (through ATP degradation) an accumulation of adenosine, which in turn, produced tonic suppression of synaptic transmission by acting on adenosine receptors [99].

\section{Astrocytes form functional neuronal-glial-vascular units and control microcirculation}

Experiments, employing in situ labelling of astroglia with fluorescent dyes (e.g. [100] as well as transgenic animals expressing variants of fluorescent proteins (such as green fluorescent protein, GFP or reef coral fluorescent proteins, RCFPs) under control of astrocyte-specific promotor (GFAP; e.g. [101, 102]) greatly assisted in visualising astroglial cells in their natural environment. This in situ imaging not only revealed an incredibly complex array of fine processes and appendages formed by the astroglia [100, 103], but also found a very specific spatial organisation of astrocytes in the grey matter. It turned out that every protoplasmic astrocyte occupies a clearly defined territorial domain, which is free from the processes of other astrocytes (Fig. 2). The area where processes of neighbouring astroglial cells overlap appeared to be very small, as only a very small portion $(<5 \%)$ of the volumes of neighbouring cells overlaps (Fig. 2). Thus astroglia divide the grey matter into distinct compartments, and within each of these compartments a single astrocyte forms contacts with all neuronal membranes and synapses residing within its confines [104]. These contacts are created by fine astroglial processes, which also often send even finer extensions, represented by filopodia or lamellipodia. These are highly dynamic structures, the lamellipodia being able to glide along neuronal surfaces, whereas filopodia are rapidly extended from the astroglial processes. These filopodia can extended for $2-6 \mu \mathrm{m}$ within 30 to $60 \mathrm{~s}$; staying elongated for several minutes and then retracting back [105]. 


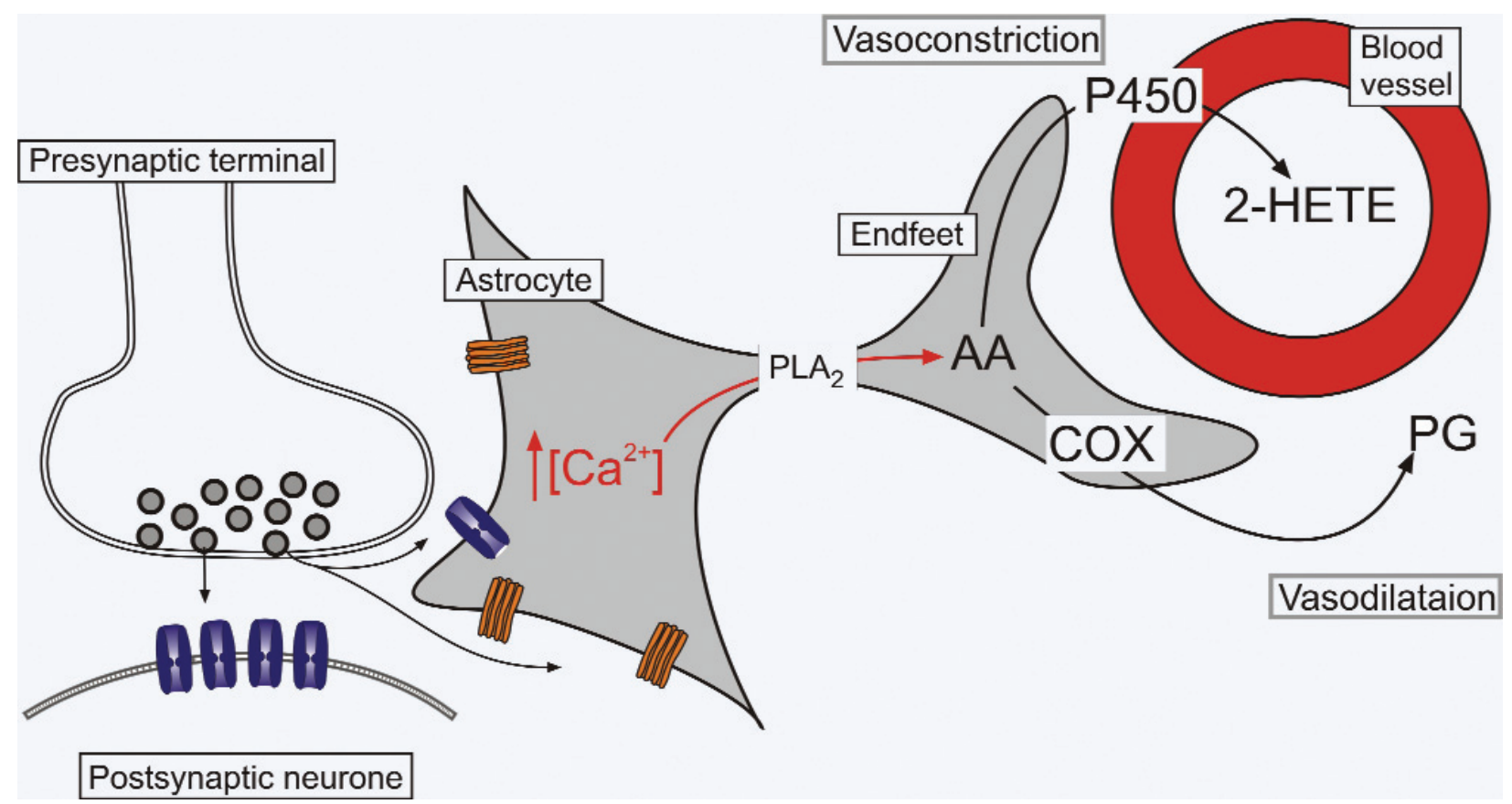

Fig. 3 Astroglial cells control brain microcirculation. Chemical signals arising from active neurones trigger $\mathrm{Ca}^{2+}$ release from the ER in the neighbouring astrocytes; this $\mathrm{Ca}^{2+}$ release initiate propagating $\mathrm{Ca}^{2+}$ wave which reach the endfoot and activates the phopsholipase $\mathrm{A}_{2}\left(\mathrm{PLA}_{2}\right)$, which in turn generate arachidonic acid (AA). Arachidonic acid is processed either by cyclooxigenase $(\mathrm{COX})$ to produce vasodilatatory prostaglandin derivatives $(\mathrm{PG})$ or is converted by cytochrome 450 (which is localised in the arteriole wall) into 20 hydroxyeicosatetraenoic acid (20HETE), which mediates the vasoconstriction.

Not only astroglial cells form contacts with all the neuronal surfaces belonging to their territory, they also provide a link between neurones and blood capillaries. Every astroglial cell sends a process towards the nearest capillary, on which it forms an endfoot. The endfeet of several astrocytes cover the capillary wall forming thus the glial-vascular interface, a part of the blood-brain barrier (BBB). The membrane of endfeet is packed with a variety of receptors (e.g. metabotropic purinoreceptors), channels (e.g. aquaporines) and transporters (e.g. glucose transporters), that most likely are instrumental in mediating the glial-capillary communications $[104,106]$. Therefore every single astrocyte integrates itself and the neurones residing within its territory with a capillary, forming thus an independent glial-neuronalvascular unit. This unit has a very important functional significance, as it links neurones with blood vessels and is instrumental in the dynamic regulation of blood supply associated with neuronal activity.

It is a universally acknowledged fact that an increase in neuronal activity rapidly increases circu- lation within the active brain area, a phenomenon defined in Sherrington's work [107] as "functional hyperemia". For a long time the cellular mechanisms responsible for coupling neuronal activity with the changes in the diameter of blood vessels (vasodilatation/vasoconstriction) remained enigmatic. In recent studies, however, the astrocytes were identified as one of the key elements in this functional coupling between nerve cells and cerebral vessels (Fig. 3). Thus, stimulation of neuronal afferents in cortical slices resulted, as expected, in dilation of neighbouring arterioles, but this afferent stimulation also triggered $\left[\mathrm{Ca}^{2+}\right]_{\mathrm{i}}$ signals in the astroglial endfeet surrounding dilating vessels through activation of metabotropic glutamate receptors (mGluRs) [108]. Pharmacological inhibition of these receptors reduced vasodilatation in response to afferent stimulation, whereas activation of mGluRs by the selective agonist trans-ACPD led to relaxation of arterioles. Similarly, direct stimulation of a single astrocyte with a patch pipette induced dilation of the part of closely apposed arteriole, which was in direct contact 
with the endfeet sent by astrocyte subjected to stimulation [108]. Astroglia-mediated vasodilatation could be blocked by aspirin, hence implying the involvement of cyclooxigenase product (e.g. prostaglandin derivatives produced from arachidonic acid). Most interestingly, in another brain region, the hippocampus, local $\left[\mathrm{Ca}^{2+}\right]$ i signals in the astroglial endfoot (produced either by focal $\mathrm{Ca}^{2+}$ uncaging or by stimulation of adrenoreceptors) triggered vasoconstriction [109]. This vasoconstriction was also mediated by the product derived from arachidonic acid; the latter can be converted into vasoconstrictive agent 20-hydroxyeicosatetraenoic acid (20-HETE) by a cytochrome P450 enzyme residing in the arteriole smooth muscle. At the present, it is not clear if this difference represents a regional specialization or whether the astrocytes are capable of initiating either type of response (vasoconstriction or vasodilatation) depending on particular circumstances. These recent data indicate that the astrocytes, through their local endfeet-vascular interactions, may initiate extremely focal changes in blood supply to support the functional activity of a single neuron-glia-vascular unit they delineate and control.

\section{Integration within neuronal-glial networks: What keys the future holds?}

The last decade has been critically important for gliology, as it produced a substantially larger amount of data on the glial morphology, physiology and development, than the entire preceding century. This new knowledge about glia raises a formidable challenge to the neuronal doctrine, which dominated neurobiology since 1890 s, and lead directly to the current dogma that the output of the brain is based, almost exclusively, on neuronal activity. Our developing understanding of the glia swiftly change their status from a mere supporter of neurones to a central position, from which they govern all aspects of the neurone's birth, life and death.

We know now that brain stem cells are represented by cells of astroglial lineage $[110,111]$, and evidence is mounting showing the radial glia as an omnipotent neural progenitor cells, acting as a main intermediate state between early neuroepithelial cells and all differentiated neural elements of the CNS, be it neurones or macroglia [112, 113]. Moreover, this theory, in fact, postulates that the neural cell lineage is in essence the radial glial/astroglial one; and neurones (as well as oligodendrocytes) are the progeny of the astroglial cells [114].

Similarly, the new knowledge about the functional organisation of the grey matter forces us to reconsider the main postulate of neuronal doctrine that the substrate for the integration of information in the central nervous system is represented by the neurones and the synapses established between them. The currently available information show that it is the astrocytes that are creating the compartmentalisation in the CNS, and it is the astrocytes that are able to integrate neurones, synapses, and brain capillaries into individual and relatively independent units. Furthermore, the astroglial syncytium, connected through gap junction communication pathways, allows a rather elaborated intercellular communication route, which permits direct translocation of ions, metabolic factors and second messengers. The resulting potential for parallel processing and integration is significant and might easily be larger, but also fuzzier, than the binary coded electrical communication within the neuronal networks. In a way, the neuronal networks may be seen as highly specialised elements of rapid delivery of information, whereas astroglial cells may represent the true substrate (or "substance", as Virchow would have called it) for information processing, integration and storage. Indeed, the number of glia, both in absolute terms and relative to the number of neurones, increases dramatically on the phylogenetic scale, together with the increase in the cortical capacity for complex processing [104]. Will this truly heretical theory, which subordinates neurones to glia, be proven correct in the end? Only the future holds a definite answer to this question.

\section{References}

1. Virchow R. Die Cellularpathologie in ihrer Begründung auf physiologische and pathologische Gewebelehre; 1858 Verlag von August Hirschfeld, Berlin.

2. Cajal Ramon y S. Contribution al conocimiento de la neuroglia del cerebro humano. Trab Lab Invest Biol. 1913; 11: 255-315.

3. Golgi C. Contribuzione alla fina Anatomia degli organi centrali del sistema nervoso. 1871; Rivista clinica di Bologna, Bologna. 
4. Exner S. Entwurf zur physiologischen Erklärung der Psychischen Erscheinungen. 1894; Deiticke.

5. Waldeyer von HWG. Dtsch Med Wschr. 1891; 44: 1213-8.

6. Schleich CL. Schmerzlose Operationen, Operationen, Örtliche Betäubung mit indiffrenten Flüssigkeiten.1894; Springer.

7. Verkhratsky A. Patching the glia reveals the functional organisation of the brain. Pflugers Arch. 2006.

8. Peters A, Palay SL, Webster HF. The fine structure of the nervous system. 1970; Harper \& Row Publishers, NY, London.

9. Sherrington CS. The integrative action of the nervous system. 1906; Charles Scribner's Sons, New York.

10. Dermietzel R. Gap junction wiring: a 'new' principle in cell-to-cell communication in the nervous system? Brain Res Rev. 1998; 26: 176-83.

11. Dermietzel R, Spray DC. Gap junctions in the brain: where, what type, how many and why? Trends Neurosci. 1993; 16: 186-92.

12. Saez JC, Berthoud VM, Branes MC, Martinez AD, Beyer EC. Plasma membrane channels formed by connexins: their regulation and functions. Physiol Rev. 2003; 83: $1359-400$

13. Theis M, Sohl G, Eiberger J, Willecke K. Emerging complexities in identity and function of glial connexins. Trends Neurosci. 2005; 28: 188-95.

14. Nagy JI, Dudek FE, Rash JE. Update on connexins and gap junctions in neurons and glia in the mammalian nervous system. Brain Res Rev. 2004; 47: 191-215.

15. Ye ZC, Wyeth MS, Baltan-Tekkok S, Ransom BR. Functional hemichannels in astrocytes: a novel mechanism of glutamate release. J Neurosci. 2003; 23: 3588-96.

16. Wallraff A, Odermatt B, Willecke K, Steinhauser C. Distinct types of astroglial cells in the hippocampus differ in gap junction coupling. Glia 2004; 48: 36-43.

17. Blomstrand F, Venance L, Siren AL, Ezan P, Hanse E, Glowinski J, Ehrenreich H, Giaume C. Endothelins regulate astrocyte gap junctions in rat hippocampal slices. Eur J Neurosci. 2004; 19: 1005-15.

18. Meme W, Ezan P, Venance L, Glowinski J, Giaume C. ATP-induced inhibition of gap junctional communication is enhanced by interleukin-1 beta treatment in cultured astrocytes. Neuroscience 2004; 126: 95-104.

19. Rouach N, Glowinski J, Giaume C. Activity-dependent neuronal control of gap-junctional communication in astrocytes. J Cell Biol. 2000; 149: 1513-26.

20. Ransom BR, Ye ZC. Gap junctions and hemichannels. 2005 in: Neuroglia, Vol., pp. 177-189 (H. Kettenmann and B. R. Ransom, Ed.) $)^{\wedge}$ ds.) Oxford University Press, New York.

21. Froes MM, Correia AH, Garcia-Abreu J, Spray DC, Campos de Carvalho AC, Neto MV. Gap-junctional coupling between neurons and astrocytes in primary central nervous system cultures. Proc Natl Acad Sci USA. 1999; 96: 7541-6.

22. Nadarajah B, Thomaidou D, Evans WH, Parnavelas JG. Gap junctions in the adult cerebral cortex: regional differences in their distribution and cellular expression of connexins. J Comp Neurol. 1996; 376: 326-42.

23. Alvarez-Maubecin V, Garcia-Hernandez F, Williams JT, Van Bockstaele EJ. Functional coupling between neurons and glia. J Neurosci. 2000; 20: 4091-8.

24. Pakhotin P, Verkhratsky A. Electrical synapses between Bergmann glial cells and Purkinje neurones in rat cerebel- lar slices. Mol Cell Neurosci. 2005; 28: 79-84.

25. Bevan S, Chiu SY, Gray PT, Ritchie JM. The presence of voltage-gated sodium, potassium and chloride channels in rat cultured astrocytes. Proc R Soc Lond B Biol Sci. 1985; 225: 299-313.

26. Verkhratsky AN, Trotter J, Kettenmann H. Cultured glial precursor cells from mouse cortex express two types of calcium currents. Neurosci Lett. 1990; 112: 194-8.

27. Sontheimer H, Ransom BR, Cornell Bell AH, Black JA, Waxman SG. $\mathrm{Na}^{+}$-current expression in rat hippocampal astrocytes in vitro: alterations during development. $J$ Neurophysiol. 1991; 65: 3-19.

28. Blankenfeld Gv G, Verkhratsky AN, Kettenmann H. $\mathrm{Ca}^{2+}$ channel expression in the oligodendrocyte lineage. Eur J Neurosci. 1992; 4: 1035-48.

29. Kirischuk S, Scherer J, Moller T, Verkhratsky A, Kettenmann H. Subcellular heterogeneity of voltagegated $\mathrm{Ca}^{2+}$ channels in cells of the oligodendrocyte lineage. Glia 1995; 13: 1-12.

30. Akopian G, Kressin K, Derouiche A, Steinhñuser C. Identified glial cells in the early postnatal mouse hippocampus display different types of $\mathrm{Ca}^{2+}$ currents. Glia 1996; 17: 181-94.

31. Verkhratsky A, Steinhauser C. Ion channels in glial cells. Brain Res Rev. 2000; 32: 380-412.

32. Verkhratsky A, Petersen $\mathbf{O H}$. The endoplasmic reticulum as an integrating signalling organelle: from neuronal signalling to neuronal death. Eur J Pharmacol. 2002; 447: 141-54.

33. Verkhratsky A. The endoplasmic reticulum and neuronal calcium signalling. Cell Calcium 2002; 32: 393-404.

34. Bootman MD, Petersen OH, Verkhratsky A. The endoplasmic reticulum is a focal point for co-ordination of cellular activity. Cell Calcium 2002; 32: 231-4.

35. Berridge MJ. The endoplasmic reticulum: a multifunctional signaling organelle. Cell Calcium 2002; 32: 235-49.

36. Verkhratsky A. Physiology and pathophysiology of the calcium store in the endoplasmic reticulum of neurons. Physiol Rev. 2005; 85: 201-79.

37. Burdakov D, Petersen $\mathbf{O H}$, Verkhratsky A. Intraluminal calcium as a primary regulator of endoplasmic reticulum function. Cell Calcium 2005; 38: 303-10.

38. Paschen W, Mengesdorf T. Endoplasmic reticulum stress response and neurodegeneration. Cell Calcium 2005; 38: 409-15.

39. Hofer AM, Machen TE. Technique for in situ measurement of calcium in intracellular inositol 1,4,5-trisphosphate-sensitive stores using the fluorescent indicator magfura-2. Proc Natl Acad Sci USA. 1993; 90: 2598-602.

40. Mogami H, Tepikin AV, Petersen OH. Termination of cytosolic $\mathrm{Ca}^{2+}$ signals: $\mathrm{Ca}^{2+}$ reuptake into intracellular stores is regulated by the free $\mathrm{Ca}^{2+}$ concentration in the store lumen. EMBO J. 1998; 17: 435-42.

41. Alonso MT, Barrero MJ, Michelena P, Carnicero E, Cuchillo I, Garcia AG, Garcia-Sancho J, Montero M, Alvarez $\mathbf{J} . \mathrm{Ca}^{2+}$-induced $\mathrm{Ca}^{2+}$ release in chromaffin cells seen from inside the ER with targeted aequorin. $J$ Cell Biol. 1999; 144: 241-54.

42. Alvarez J, Montero M. Measuring $\left[\mathrm{Ca}^{2+}\right]$ in the endoplasmic reticulum with aequorin. Cell Calcium 2002; 32: 251-60.

43. Solovyova N, Verkhratsky A. Monitoring of free calcium 
in the neuronal endoplasmic reticulum: an overview of modern approaches. J Neurosci Methods 2002; 122: 1-12.

44. Solovyova N, Veselovsky N, Toescu EC, Verkhratsky A. $\mathrm{Ca}^{2+}$ dynamics in the lumen of the endoplasmic reticulum in sensory neurons: direct visualization of $\mathrm{Ca}^{2+}{ }_{\text {-induced }}$ $\mathrm{Ca}^{2+}$ release triggered by physiological $\mathrm{Ca}^{2+}$ entry. $E M B O$ J. 2002; 21: 622-30.

45. Solovyova N, Verkhratsky A. Neuronal endoplasmic reticulum acts as a single functional $\mathrm{Ca}^{2+}$ store shared by ryanodine and inositol-1,4,5-trisphosphate receptors as revealed by intra-ER $\left[\mathrm{Ca}^{2+}\right]$ recordings in single rat sensory neurones. Pflugers Arch. 2003; 446: 447-54.

46. Hamilton SL. Ryanodine receptors. Cell Calcium 2005; 38: 253-60.

47. Bezprozvanny I. The inositol 1,4,5-trisphosphate receptors. Cell Calcium 2005; 38: 261-72.

48. Galione A, Ruas M. NAADP receptors. Cell Calcium 2005; 38: 273-80

49. Berridge MJ, Bootman MD, Roderick HL. Calcium signalling: dynamics, homeostasis and remodelling. Nat Rev Mol Cell Biol . 2003; 4: 517-29.

50. Verkhratsky A, Kettenmann H. Calcium signalling in glial cells. Trends Neurosci. 1996; 19: 346-52.

51. Verkhratsky A, Solovyova N, Toescu EC. Calcium excitability of glial cells. 2002 in: Glia in synaptic transmission, Vol., pp. 99-109 (A. Volterra, et al., Ed.)^Eds.) OUP, Oxford.

52. Deitmer JW, Verkhratsky AJ, Lohr C. Calcium signalling in glial cells. Cell Calcium 1998; 24: 405-16.

53. Verkhratsky A, Orkand RK, Kettenmann H. Glial calcium: homeostasis and signaling function. Physiol Rev. 1998; 78: 99-141.

54. Beck A, Nieden RZ, Schneider HP, Deitmer JW. Calcium release from intracellular stores in rodent astrocytes and neurons in situ. Cell Calcium 2004; 35: 47-58.

55. Tuschick S, Kirischuk S, Kirchhoff F, Liefeldt L, Paul M, Verkhratsky A, Kettenmann H. Bergmann glial cells in situ express endothelinB receptors linked to cytoplasmic calcium signals. Cell Calcium 1997; 21: 409-19.

56. Toescu EC, Moller T, Kettenmann H, Verkhratsky A. Long-term activation of capacitative $\mathrm{Ca}^{2+}$ entry in mouse microglial cells. Neuroscience 1998; 86: 925-35.

57. Hartmann J, Verkhratsky A. Relations between intracellular $\mathrm{Ca}^{2+}$ stores and store-operated $\mathrm{Ca}^{2+}$ entry in primary cultured human glioblastoma cells. J Physiol. 1998; 513: 411-24.

58. Jung S, Pfeiffer F, Deitmer JW. Histamine-induced calcium entry in rat cerebellar astrocytes: evidence for capacitative and non-capacitative mechanisms. $J$ Physiol. 2000; 527: 549-61.

59. Golovina VA. Visualization of localized store-operated calcium entry in mouse astrocytes. Close proximity to the endoplasmic reticulum. J Physiol 2005; 564: 737-49.

60. Kirischuk S, Scherer J, Kettenmann H, Verkhratsky A. Activation of $\mathrm{P}_{2}$-purinoreceptors triggered $\mathrm{Ca}^{2+}$ release from $\mathrm{Ins}_{3}$-sensitive internal stores in mammalian oligodendrocytes. J Physiol. 1995; 483: 41-57.

61. Kirischuk S, Moller T, Voitenko N, Kettenmann H, Verkhratsky A. ATP-induced cytoplasmic calcium mobilization in Bergmann glial cells. J Neurosci. 1995; 15: 7861-71.

62. Aguado F, Espinosa-Parrilla JF, Carmona MA, Soriano E. Neuronal activity regulates correlated network properties of spontaneous calcium transients in astrocytes in situ. J Neurosci. 2002; 22: 9430-44.

63. Nett WJ, Oloff SH, McCarthy KD. Hippocampal astrocytes in situ exhibit calcium oscillations that occur independent of neuronal activity. J Neurophysiol. 2002; 87: 528-37.

64. Parri HR, Crunelli V. The role of $\mathrm{Ca}^{2+}$ in the generation of spontaneous astrocytic $\mathrm{Ca}^{2+}$ oscillations. Neuroscience 2003; 120: 979-92.

65. Parri HR, Gould TM, Crunelli V. Spontaneous astrocytic $\mathrm{Ca}^{2+}$ oscillations in situ drive NMDAR-mediated neuronal excitation. Nat Neurosci. 2001; 4: 803-12.

66. Cornell Bell AH, Finkbeiner SM, Cooper MS, Smith SJ. Glutamate induces calcium waves in cultured astrocytes: long- range glial signaling. Science 1990; 247: 470-3.

67. Cornell Bell AH, Finkbeiner SM. $\mathrm{Ca}^{2+}$ waves in astrocytes. Cell Calcium 1991; 12: 185-204.

68. Bennett MR, Farnell L, Gibson WG. A quantitative model of purinergic junctional transmission of calcium waves in astrocyte networks. Biophys J. 2005; 89: 2235-50.

69. Suadicani SO, Flores CE, Urban-Maldonado M, Beelitz M, Scemes E. Gap junction channels coordinate the propagation of intercellular $\mathrm{Ca}^{2+}$ signals generated by P2Y receptor activation. Glia 2004; 48: 217-29.

70. Anderson CM, Bergher JP, Swanson RA. ATP-induced ATP release from astrocytes. $J$ Neurochem 2004; 88 : 246-56.

71. Arcuino G, Lin JH, Takano T, Liu C, Jiang L, Gao Q, Kang J, Nedergaard M. Intercellular calcium signaling mediated by point-source burst release of ATP. Proc Natl Acad Sci USA. 2002; 99: 9840-5.

72. Stout CE, Costantin JL, Naus CC, Charles AC. Intercellular calcium signaling in astrocytes via ATP release through connexin hemichannels. $J$ Biol Chem. 2002; 277: 10482-8.

73. Giaume C, Venance L. Intercellular calcium signaling and gap junctional communication in astrocytes. Glia 1998; 24: 50-64.

74. Cambier D, Pessac B. Spontaneous glutamate release by a "fibrous"-like cerebellar astroglial cell clone. $J$ Neurochem. 1989; 53: 551-5.

75. Bezzi P, Gundersen V, Galbete JL, Seifert G, Steinhauser C, Pilati E, Volterra A. Astrocytes contain a vesicular compartment that is competent for regulated exocytosis of glutamate. Nat Neurosci 2004; 7: 613-20.

76. Zhang Q, Pangrsic T, Kreft M, Krzan M, Li N, Sul JY, Halassa M, Van Bockstaele E, Zorec R, Haydon PG. Fusion-related release of glutamate from astrocytes. $\mathrm{J} \mathrm{Biol}$ Chem. 2004; 279: 12724-33.

77. Montana V, Ni Y, Sunjara V, Hua X, Parpura V. Vesicular glutamate transporter-dependent glutamate release from astrocytes. J Neurosci. 2004; 24: 2633-42.

78. Kreft M, Stenovec M, Rupnik M, Grilc S, Krzan M, Potokar M, Pangrsic T, Haydon PG, Zorec R. Properties of $\mathrm{Ca}(2+)$-dependent exocytosis in cultured astrocytes. Glia 2004; 46: 437-45.

79. Hua X, Malarkey EB, Sunjara V, Rosenwald SE, Li WH, Parpura V. $\mathrm{Ca}^{2+}$-dependent glutamate release involves two classes of endoplasmic reticulum $\mathrm{Ca}^{2+}$ stores in astrocytes. J Neurosci Res 2004; 76: 86-97.

80. Volterra A, Meldolesi J. Astrocytes, from brain glue to 
communication elements: the revolution continues. Nat Rev Neurosci. 2005; 6: 626-40.

81. Takano T, Kang J, Jaiswal JK, Simon SM, Lin JH, Yu Y, Li Y, Yang J, Dienel G, Zielke HR, Nedergaard M. Receptor-mediated glutamate release from volume sensitive channels in astrocytes. Proc Natl Acad Sci USA. 2005; 102: 16466-71.

82. Duan S, Anderson CM, Keung EC, Chen Y, Swanson RA. P2X7 receptor-mediated release of excitatory amino acids from astrocytes. $J$ Neurosci. 2003; 23: 1320-8.

83. Hassinger TD, Atkinson PB, Strecker GJ, Whalen LR, Dudek FE, Kossel AH, Kater SB. Evidence for glutamate-mediated activation of hippocampal neurons by glial calcium waves. J Neurobiol. 1995; 28: 159-70.

84. Sanzgiri RP, Araque A, Haydon PG. Prostaglandin E(2) stimulates glutamate receptor-dependent astrocyte neuromodulation in cultured hippocampal cells. $J$ Neurobiol. 1999; 41: 221-9.

85. Araque A, Sanzgiri RP, Parpura V, Haydon PG. Calcium elevation in astrocytes causes an NMDA receptor-dependent increase in the frequency of miniature synaptic currents in cultured hippocampal neurons. $J$ Neurosci. 1998; 18: 6822-9.

86. Araque A, Parpura V, Sanzgiri RP, Haydon PG. Glutamate-dependent astrocyte modulation of synaptic transmission between cultured hippocampal neurons. Eur J Neurosci. 1998; 10: 2129-42.

87. Newman EA. New roles for astrocytes: regulation of synaptic transmission. Trends Neurosci. 2003; 26: 536-42.

88. Perea G, Araque A. Glial calcium signaling and neuronglia communication. Cell Calcium 2005; 38: 375-82.

89. Pasti L, Volterra A, Pozzan T, Carmignoto G. Intracellular calcium oscillations in astrocytes: a highly plastic, bidirectional form of communication between neurons and astrocytes in situ. J Neurosci. 1997; 17: 7817-30.

90. Bezzi P, Carmignoto G, Pasti L, Vesce S, Rossi D, Rizzini BL, Pozzan T, Volterra A. Prostaglandins stimulate calcium-dependent glutamate release in astrocytes. Nature 1998; 391: 281-5.

91. Angulo MC, Kozlov AS, Charpak S, Audinat E. Glutamate released from glial cells synchronizes neuronal activity in the hippocampus. J Neurosci. 2004; 24: 6920-7.

92. Kang J, Jiang L, Goldman SA, Nedergaard M. Astrocyte-mediated potentiation of inhibitory synaptic transmission. Nat Neurosci. 1998; 1: 683-92.

93. Liu QS, Xu Q, Arcuino G, Kang J, Nedergaard M. Astrocyte-mediated activation of neuronal kainate receptors. Proc Natl Acad Sci USA. 2004; 101: 3172-7.

94. Guthrie PB, Knappenberger J, Segal M, Bennett MV, Charles AC, Kater SB. ATP released from astrocytes mediates glial calcium waves. J Neurosci. 1999; 19: $520-8$.

95. Schell MJ, Molliver ME, Snyder SH. D-serine, an endogenous synaptic modulator: localization to astrocytes and glutamate-stimulated release. Proc Natl Acad Sci USA. 1995; 92: 3948-52.

96. Oliet SH, Piet R, Poulain DA, Theodosis DT. Glial modulation of synaptic transmission: Insights from the supraoptic nucleus of the hypothalamus. Glia 2004; 47: 258-67.

97. Volterra A, Steinhauser C. Glial modulation of synaptic transmission in the hippocampus. Glia 2004; 47: 249-57.
98. Zhang JM, Wang HK, Ye CQ, Ge W, Chen Y, Jiang ZL, Wu CP, Poo MM, Duan S. ATP released by astrocytes mediates glutamatergic activity-dependent heterosynaptic suppression. Neuron 2003; 40: 971-82.

99. Pascual O, Casper KB, Kubera C, Zhang J, RevillaSanchez R, Sul JY, Takano H, Moss SJ, McCarthy K, Haydon PG. Astrocytic purinergic signaling coordinates synaptic networks. Science 2005; 310: 113-6.

100. Ogata K, Kosaka T. Structural and quantitative analysis of astrocytes in the mouse hippocampus. Neuroscience 2002; 113: 221-33.

101. Nolte C, Matyash M, Pivneva T, Schipke CG, Ohlemeyer C, Hanisch UK, Kirchhoff F, Kettenmann H. GFAP promoter-controlled EGFP-expressing transgenic mice: a tool to visualize astrocytes and astrogliosis in living brain tissue. Glia 2001; 33: 72-86.

102. Hirrlinger PG, Scheller A, Braun C, QuintelaSchneider M, Fuss B, Hirrlinger J, Kirchhoff F. Expression of reef coral fluorescent proteins in the central nervous system of transgenic mice. Mol Cell Neurosci. 2005; 30: 291-303.

103. Bushong EA, Martone ME, Jones YZ, Ellisman MH. Protoplasmic astrocytes in CA1 stratum radiatum occupy separate anatomical domains. J Neurosci. 2002; 22: 183-92.

104. Nedergaard M, Ransom B, Goldman SA. New roles for astrocytes: redefining the functional architecture of the brain. Trends Neurosci. 2003; 26: 523-30.

105. Hirrlinger J, Hulsmann S, Kirchhoff F. Astroglial processes show spontaneous motility at active synaptic terminals in situ. Eur J Neurosci. 2004; 20: 2235-9.

106. Simard M, Arcuino G, Takano T, Liu QS, Nedergaard M. Signaling at the gliovascular interface. $J$ Neurosci. 2003; 23: 9254-62.

107. Roy CS, Sherrington CS. On the regulation of blood suppy of the brain. J Physiol. 1890; 11: 85-108.

108. Zonta M, Angulo MC, Gobbo S, Rosengarten B, Hossmann KA, Pozzan T, Carmignoto G. Neuron-toastrocyte signaling is central to the dynamic control of brain microcirculation. Nat Neurosci. 2003; 6: 43-50.

109. Mulligan SJ, MacVicar BA. Calcium transients in astrocyte endfeet cause cerebrovascular constrictions. Nature 2004; 431: 195-9.

110. Doetsch F. The glial identity of neural stem cells. Nat Neurosci. 2003; 6: 1127-34.

111. Garcia AD, Doan NB, Imura T, Bush TG, Sofroniew MV. GFAP-expressing progenitors are the principal source of constitutive neurogenesis in adult mouse forebrain. Nat Neurosci. 2004; 7: 1233-41.

112. Goldman S. Glia as neural progenitor cells. Trends Neurosci. 2003; 26: 590-6.

113. Gotz M, Barde YA. Radial glial cells defined and major intermediates between embryonic stem cells and CNS neurons. Neuron 2005; 46: 369-72.

114. Alvarez-Buylla A, Garcia-Verdugo JM, Tramontin AD. A unified hypothesis on the lineage of neural stem cells. Nat Rev Neurosci. 2001; 2: 287-93.

115. Matyash M, Matyash V, Nolte C, Sorrentino V, Kettenmann H. Requirement of functional ryanodine receptor type 3 for astrocyte migration. FASEB J. 2002; 16: 84-6. 